\title{
Phenolic substances in Ailanthus glandulosa Desf
}

\author{
Karolina Pekala, Katarzyna Wawrzusiszyn, Anna Bogucka-KockA*
}

Chair and Department of Pharmaceutical Botany, Medical University of Lublin

\begin{tabular}{l}
\hline ARTICLE INFO \\
\hline Received 23 May 2014 \\
Accepted 29 May 2014 \\
\hline
\end{tabular}

Keywords:

Ailanthus glandulosa Desf., phenolic acids,

TLC chromatography.

\begin{abstract}
The aim of this work was the isolation and identification of phenolic acids from fruit and leaves of Ailanthus glandulosa Desf. The methods used in the isolation and identification of the compounds were: isolation of phenolic acids modified by Ibrahim and Towers, acidic and alkaline hydrolysis by Schmidtlein and Herrmann and identification of phenolic acids in the isolated fraction of two-dimensional thin layer chromatography (TLC) on cellulose plates. In the course of the study, the presence of phenolic acids in leaves and fruit of Ailanthus glandulosa Des $f$ was confirmed. Overall, proportions of 15 phenolic acids were found and identified in the analyzed material. These are: gallic acid, ellagic acid, caffeic acid, gentisic acid, protocatechuic acid, p-hydroxybenzoic acid, m-hydroxybenzoic acid, ferulic acid, p-coumaric acid, syryngic acid, vanillic acid, salicylic acid, 2-hydroxy-4methoxybenzoic acid, 2,5-dimethoxycinnamic, p-hydroxyphenylacetic acid, and 3 other compounds named $\mathrm{A}, \mathrm{B}, \mathrm{C}$, whose identification was not possible due to the lack of suitable reference patterns. Studies have shown that leaves and fruit of the plant Ailanthus glandulosa Desf. contain a large number of phenolic acids which possess many important pharmacological activities.
\end{abstract}

\section{INTRODUCTION}

It Ailanthus glandulosa Desf. belongs to the Simarubaceae family and is commonly known as the tree of life or Chinese sumac. Originally it comes from northern China and was brought to Europe in 1751. For centuries it has been used in traditional Chinese medicine to treat diarrhea and heavy menstrual bleeding [10]. Asian folk medicine also uses a decoction of the leaves of this plant in the treatment of ulcers, malaria, heart palpitation, asthma, and in fever reduction [24].

Currently, Ailanthus glandulosa Desf. is a plant commonly occurring on the European continent and in North America [9].

Previous phytochemical studies on Ailanthus glandulosa Desf. reported a high content of alkaloids and bitter substances, which were attributed very distinct pharmacological efficacy [29]. Those studies showed that Ailanthus glandulosa Desf. was mainly a source of alkaloids and gentian substances. For a long time clear pharmacological efficacy was attributed to gentian substances. The most frequently occurring gentian substances in this plant include: ailanthone [17], uassine [5], neoquassine [5], amarolide [3],

Corresponding author

e-mail: anna.kocka@umlub.pl shinjulactone [11] and many others. The most frequently occurring alkaloids in this plant include: canthin-6-one [19], canthin-6-one-3-oxide [20], 1-methoxycanthin-6-one [20], 1 -acetyl-4-methoxy- $\beta$-Carboline [19] and others. Other compounds which are present in Ailanthus glandulosa Desf. are: 2,6 -dimethoxychinon [4], scopoletin [28], $\beta$-sitosterol [28], apigenin [27], kaempferol [27], monoacylglycerol [6], triacylglycerol [6].

The methods used to identify those substances were chromatographic analysis and spectral analysis. The purpose of the study was to determine the presence and identify phenolic acids that occur in Ailanthus glandulosa Desf.

Phenolic acids are a group of secondary metabolites that are widespread in the plant kingdom. They are characterized by diverse chemical structure and numerous pharmacological properties. Their molecules contain two functional groups: a carboxyl group and a phenolic hydroxyl group [16]. Because of the chemical structure, they can be divided into derivatives of cinnamic acid and benzoic acid, which differ from each other in the number of hydroxyl groups and the placement of the methoxyl substitution [14].

One of the most important pharmacological properties of phenolic acids is their antioxidant activity. It mainly concerns derivatives of cinnamic acid. It is connected with the number of hydroxyl and methoxyl groups, which are attached to the phenyl ring. Due to their antioxidant properties phenolic acids are a group of plant compounds 
that inhibit and delay the early stages of tumor development [8].

Other pharmacological effects of phenolic acids are: antipyretic, antibacterial, anti-inflammatory, antirheumatic, antifungal, anthelmintic, cholagogic, choleretic and immunostimulant $[2,12]$.

\section{MATERIAL AND METHODS}

Material for the study. The raw material for the study were leaves and fruit of Alianthus glandulosa Desf. from the natural state. Leaves were collected in August, while fruit were harvested fully ripened. The collected material was dried at room temperature. Next, it was ground and sieved with a sieve according to pharmacopoeial requirements. Two hundred and thirty-two grams of leaves and 184 grams of fruit were used for the study.

\section{RESEARCH METHODS}

Preparation of extracts chloroform and petroleum ether. Properly weighed and crushed material was placed in a Soxhlet apparatus. Then, it was subjected to 36-hour continuous periodic extraction with petroleum ether and then chloroform (at the boiling temperature of the solvent).

Preparation of the methanol extract. After extraction with petroleum ether and chloroform the plant material was extracted three times with methanol in a hot water bath. Three steps of extraction with methanol:

\begin{tabular}{|c|c|c|}
\hline Extraction & Amount of methanol & Time of heating \\
\hline I & 8 times the amount of $80 \%$ methanol & $2 \mathrm{~h}$ \\
\hline II & 7 times the amount of $80 \%$ methanol & $1 \mathrm{~h}$ \\
\hline III & 7 times the amount of $60 \%$ methanol & $1 \mathrm{~h}$ \\
\hline
\end{tabular}

Finally, the methanol extracts were combined and concentrated. The dry residue was digested in $350 \mathrm{ml}$ of boiling water. After 24 hours the precipitated ballast was filtered off and discarded, whereas the resulting aqueous fraction was subjected to further study. The same course of analysis was used for both investigated materials.

Separation of free phenolic acids fraction A. After obtaining the aqueous fraction (W1W) we subjected it to 10 -fold extraction with diethyl ether. The aqueous fraction (W2W) was hydrolyzed and the ether layer was washed 10 times with $5 \%$ aqueous sodium bicarbonate solution. The combined aqueous bicarbonate extracts were acidified with hydrochloric acid to $\mathrm{pH}=2$. The obtained fraction was extracted 10 times with diethyl ether and then dried with anhydrous sodium sulfate. Finally, the solvent was filtered and evaporated in a vacuum evaporator. Using this method we received a free phenolic acids fraction A from the leaves and fruit of Ailanthus glandulosa Desf.

The processes of hydrolysis of bound phenolic acids were performed according to Schmidtlein and Herrmann [25].

Separation of fraction B of phenolic acids released by acid hydrolysis. Acid hydrolysis was performed on the half of the earlier collected aqueous solution (W2W). In order to obtain $5 \%$ solution, concentrated sulfuric acid was poured. Next, the mixture was heated in a boiling water bath under reflux condenser for $2 \mathrm{~h}$. After cooling the mixture, the entire contents of the flask were filtered and the received hydrolyzate was extracted 10 times with diethyl ether. The aqueous fraction was removed and the ether fraction underwent the same procedure as in the case of extraction of fraction A. Thus, we obtained fraction B of phenolic acids released by acid hydrolysis from the leaves and fruit of Ailanthus glandulosa Desf.

Separation of fraction $\mathrm{C}$ of phenolic acids released by alkaline hydrolysis. Alkaline hydrolysis was performed on the other half of the previously collected aqueous solution (W2W). One gram of sodium borohydride was added to the solution under stirring and by adding saturated barium hydroxide the solution was adjusted to $\mathrm{pH} 12-13$. The solution obtained in this way was heated in a boiling water bath under reflux condenser for $15 \mathrm{~min}$. After cooling, concentrated sulfuric acid was added to the hydrolyzate to obtain a solution at $\mathrm{pH}=1.5$. The received precipitate of barium sulfate was filtered off and the filtrate was extracted 10 times with diethyl ether. The further procedure was the same as in the case of extraction of fraction A. Thus, we obtained fraction $\mathrm{C}$ of phenolic acids released by alkaline hydrolysis from the leaves and fruit of Ailanthus glandulosa Desf.

Identification of phenolic acids in the isolated fractions was performed by two-dimensional thin layer chromatography (TLC) on cellulose plates [26].

Chromatographic identification of phenolic acids. Phenolic acids fractions, which were isolated from the leaves and fruit of Ailanthus glandulosa Desf. were analyzed by two-dimensional thin layer chromatography (TLC) on cellulose plates. In order to perform the test, we used plates of the Merck company in horizontal chambers - type DS [7], applying the following developing systems [26]: I benzene-methanol-acetonitrile-acetic acid (80:10:5:5) II sodium formate-formic acid-water (10:1:200)

Before developing the plates in a first direction, they were conditioned for $5 \mathrm{~min}$ in the system: benzene-methanol-acetic acid (90:5:5). The received chromatograms were viewed under UV light before and after activation of ammonia vapor and visible light after spraying the following reagents:

I R: $1 \%$ aqueous solution of ferric chloride[13],

II R: diazotized sulphanilic acid in $10 \%$ sodium carbonate solution (KS ) [15],

III R: diazotized p-nitroaniline in $20 \%$ sodium carbonate solution (p- NA) [22].

Phenolic acids were identified by the position of the fluorescence in UV light and after exposure to ammonia, comparing the color of the spots on the analyzed chromatograms with patterns of standard chromatograms.

\section{RESULTS AND DISCUSSION}

In the course of the study, the presence of phenolic acids in leaves and fruit of Ailanthus glandulosa Desf was confirmed. Overall, 15 phenolic acids were found and identified in the analyzed material.

Fractions of phenolic acids: the free phenolic fraction A and the fractions released after acid and alkaline hydrolysis - B and C, respectively, were analyzed by two-dimensional 
thin layer chromatography (2D-TLC) according to the standards [Tab 1,2].

Table 1. The content of phenolic acids in different fractions of leaves and fruit of Ailanthus glandulosa Desf.

\begin{tabular}{|c|l|c|c|c|c|c|c|}
\hline \multirow{2}{*}{ Lp. } & \multirow{2}{*}{ Phenolic acid } & \multicolumn{3}{|c|}{ Fruit } & \multicolumn{3}{|c|}{ Leaves } \\
\cline { 2 - 8 } & & A & B & C & A & B & C \\
\hline 1. & ellagic & ++ & + & + & ++ & ++ & + \\
\hline 2. & gallic & +++ & + & ++ & ++ & +++ & +++ \\
\hline 3. & caffeic & + & ++ & ++ & + & + & +++ \\
\hline 4. & protocatechuic & + & + & + & +++ & + & + \\
\hline 5. & gentisic & + & + & + & - & + & + \\
\hline 6. & p-hydroxybenzoic & ++ & ++ & +++ & + & ++ & ++ \\
\hline 7. & m-hydroxybenzoic & + & + & + & - & - & - \\
\hline 8. & p-coumaric & ++ & ++ & ++ & ++ & ++ & ++ \\
\hline 9. & ferulic & - & ++ & ++ & - & ++ & ++ \\
\hline 10. & vanillic & + & ++ & ++ & + & ++ & ++ \\
\hline 11. & syringic & + & ++ & + & - & - & + \\
\hline 12. & salicylic & + & + & + & - & + & + \\
\hline 13. & $\begin{array}{l}\text { 2-hydroxy-4- } \\
\text { methoxybenzoic }\end{array}$ & - & - & - & - & - & + \\
\hline 14. & $\begin{array}{l}2,5-\text {-dimetho- } \\
\text { xycinnamic }\end{array}$ & - & - & - & ++ & - & - \\
\hline 15. & $\begin{array}{l}\text { p-hydro- } \\
\text { xyphenylacetic }\end{array}$ & + & + & - & - & + & - \\
\hline 16. & compound A & ++ & - & - & ++ & - & - \\
\hline 17. & compound B & ++ & - & - & ++ & - & - \\
\hline 18. & compound C & - & +++ & - & - & - & - \\
\hline
\end{tabular}

Table 2. The fluorescence and color reactions of phenolic acids detected in different fractions of leaves and fruit of Ailanthus glandulosa Desf.

\begin{tabular}{|c|c|c|c|c|c|c|}
\hline \multirow{2}{*}{ Lp. } & \multirow{2}{*}{ Phenolic acid } & \multicolumn{5}{|c|}{ Spot color (absorption) } \\
\hline & & UV & $\mathrm{UV}+\mathrm{NH}_{3}$ & $\mathrm{FeCl}_{3}$ & AS & $\mathrm{p}-\mathrm{NA}$ \\
\hline 1. & ellagic & - & - & brown & $\begin{array}{l}\text { light- } \\
\text { brown }\end{array}$ & brown-red \\
\hline 2. & gallic & - & absorption & grey & $\begin{array}{l}\text { light- } \\
\text { brown }\end{array}$ & grey-violet \\
\hline 3. & caffeic & blue & blue & $\begin{array}{l}\text { brown- } \\
\text { green }\end{array}$ & brown & brown \\
\hline 4. & protocatechuic & - & absorption & $\begin{array}{c}\text { brown- } \\
\text { blue }\end{array}$ & brown & red-brown \\
\hline 5. & gentisic & blue & yellow & blue & grey & grey-green \\
\hline 6. & p-hydroxybenzoic & - & - & yellow & yellow & red \\
\hline 7. & m-hydroxybenzoic & - & - & - & yellow & red \\
\hline 8. & p-coumaric & - & violet-blue & $\begin{array}{c}\text { light } \\
\text { brown }\end{array}$ & red & $\begin{array}{l}\text { brown- } \\
\text { blue }\end{array}$ \\
\hline 9. & ferulic & blue & blue & $\begin{array}{l}\text { light- } \\
\text { brown }\end{array}$ & violet-blue & $\begin{array}{l}\text { brown- } \\
\text { blue }\end{array}$ \\
\hline 10. & vanillic & - & - & - & orange & violet \\
\hline 11. & syringic & - & - & $\begin{array}{l}\text { dark- } \\
\text { brown }\end{array}$ & violet-red & blue \\
\hline 12. & salicylic & violet & violet & $\begin{array}{l}\text { light } \\
\text { brown }\end{array}$ & yellow & red \\
\hline 13. & \begin{tabular}{|l|} 
2-hydroxy-4- \\
methoxybenzoic
\end{tabular} & - & - & $\begin{array}{l}\text { light- } \\
\text { brown }\end{array}$ & yellow & brown \\
\hline 14. & $\begin{array}{l}\text { 2,5-dimetho- } \\
\text { xycinnamic }\end{array}$ & celadon & - & - & - & pink \\
\hline 15. & $\begin{array}{l}\text { p-hydro- } \\
\text { xyphenylacetic }\end{array}$ & - & - & - & pink-blue & violet \\
\hline 16. & compound A & $\begin{array}{c}\text { absorpion } \\
\text { violet }\end{array}$ & - & dark-violet & $\begin{array}{c}\text { light } \\
\text { yellow }\end{array}$ & beige \\
\hline 17. & compound B & $\begin{array}{c}\text { absorption } \\
\text { violet }\end{array}$ & - & dark-violet & $\begin{array}{c}\text { light } \\
\text { yellow }\end{array}$ & beige \\
\hline 18. & compound C & $\begin{array}{l}\text { dark- } \\
\text { brown }\end{array}$ & red-brown & black & $\begin{array}{l}\text { reddish- } \\
\text { brown }\end{array}$ & beige \\
\hline
\end{tabular}

Legend: UV ultraviolet light (approximately $360 \mathrm{~nm}$ ); $\mathrm{NH}_{3}+\mathrm{UV}-$ spots under $\mathrm{UV}$ light after operation of the ammonia vapor; $\mathrm{FeCl}_{3}-1 \%$ aqueous solution; D-SA-diazoited sulfanilic acid in $10 \% \mathrm{Na}_{2} \mathrm{CO}_{3}$ water solution; p-NA - p- nitroanilina diazoited in $20 \% \mathrm{Na}_{2} \mathrm{CO}_{3}$ water solution.

The objective of the phytochemical study was to analyze the phenolic compounds in the leaves and fruit of Ailanthus glandulosa Desf. The study comprised the isolation and identification of the fraction of free phenolic acids and the fractions released after acid or alkaline hydrolysis. Previous studies concerning the leaves of Ailanthus glandulosa Desf. revealed the presence of only 3 phenolic acids. They were: gallic acid [30], caffeic [18] and ellagic [21]. Our study confirmed the presence of the three acids in the examined raw material and allowed for the identification of other acids found in the plant Ailanthus altissima Desf.

Based on this study the quantitative proportions of 15 phenolic acids were identified and determined for the first time. Commonly occurring acids, present in all the fractions were the tested acids: ellagic, gallic, caffeic, protocatechuic, p-hydroxybenzoic, p-coumaric and vanillic. In the leaves and fruit, the most dominant acids were: gallic, caffeic, p-hydroxybenzoic, p-coumaric and vanillic. The presence of m-hydroxybenzoic acid was revealed only in the fruit of Ailanthus glandulosa Desf. On the other hand, 2-hydroxy4-methoxybenzoic and 2,5 - dimethoxycinnamic acids were found only in the leaves. Gentisic acid did not occur only in fraction A of free phenolic acids contained in the leaves. Ferulic acid was found in fractions B and C, both in the leaves and fruit, whereas there was a lack of it in fraction $\mathrm{A}$ of both raw materials. Syringic acid was present in all the fractions obtained from the fruit Ailanthus glandulosa Desf. There was a lack of it in fractions A and B of the leaves. Salicylic acid was not found in the A fraction.

The test materials also included compounds named A, B and $\mathrm{C}$. Compounds A and B were present only in the fractions containing free phenolic acids from both leaves and fruit, while compound $\mathrm{C}$ was present in a significant quantity in fraction $\mathrm{B}$ of the fruit.

\section{CONCLUSION}

The conducted study enabled us to identify 15 phenolic acids in leaves and fruit of Ailanthus glandulosa Desf. It confirmed the presence of 3 phenolic acids: gallic, caffeic and ellagic acid, whose presence had been found in previous studies. Our study made it possible for the first time to identify the presence of the following acids: protocatechuic, gentisic, p- hydroxybenzoic, m-hydroxybenzoic, p-coumaric, ferulic, vanillic, syringic, salicylic, 2-hydroxy4-methoxybenzoic, 2,5-dimethoxycinnamic, p-hydroxyphenylacetic and 3 compounds named A, B and C. The research work had innovative character, because for the first time it detected the presence of the above-mentioned phenolic acids in leaves and fruit of Ailanthus glandulosa Desf. Therefore, Ailanthus glandulosa Desf. is recognized as a rich source of these compounds, which have very important and valuable pharmacological properties.

\section{REFERENCES}

1. Borkowski B.: Fenolokwasy i ich estry. Cz. I, Herba Polonica, 39, 71-83, 1993 [In Polish].

2. Borkowski B.: Fenolokwasy i ich estry. Cz. II, Herba Polonica, 39, 139, 1993 [In Polish]

3. Casinovi C.G. et al.: Occurrence of bitter substances related to quassin in Ailanthus glandulosa. Tetrahedon Letters., 27, 2273, 1965.

4. Casinovi C.G., Grandolini G. Bitter substances contained in Ailanthus altissmia. Atti. Acad. Nazl. Lincei, rend., Classe Sci. Fis., Mat. Nat., $35,384,1963$. 
5. Chiarlo B., Pinca MC. Research on the constituents of the bark of the subspontaneous Ailanthus glandules Desf. of Liguria. I. Identification of two amaroids quassine and nequassine. Boll. Chim. Farm., 104, 8, 485, 1965.

6. Clair-Maczulajtys D., Bory G.: Lipids from thee glandular trichome of Ailanthus altissima. Phytochem., 24, 1599, 1985.

7. Dzido T., Soczewiński E.: Modifaction of horizontal sandwich chamber for thin layer chromatography. J. Chromatogr., 516, 461, 1990.

8. Goufo P., Trindade H.: Rice antioxidants: phenolic acids, flavonoids, anthocyanins, proanthocyanidins, tocopherols, tocotrienols, $\gamma$-oryzanol, and phytic acid. Food Sci. Nutr., 2, 75, 2014.

9. Herrick N.J. et al.: Host-range testing of Eucryptorrhynchus brandti (Coleoptera: Curculionidae), a candidate for biological control of tree-of-heaven, Ailanthus altissima. Environ Entomol., 41, 118, 2012.

10. Hong Z.L. et al.: Tetracyclic triterpenoids and terpenylated coumarins from the bark of Ailanthus altissima ("Tree of Heaven"). Phytochem., 86, 159, 2013.

11. Ishibashi M. et al.: Shinjudilactone, a new bitter principle from Ailanthus altissima. Chem. Lett., 11, 1597, 1981.

12. Itoh A. et al.: Hepatoprotective effect of syringic acid and vanillic acid on CCl4-induced liver injury. Biol. Pharm. Bull., 33, 983, 2010.

13. Jerzmanowska Z.: Substancje roślinne. Metody wyodrębniania. PWN, Warszawa 1967 [In Polish].

14. Kohlmünzer S.: Farmakognozja. Wydawnictwo Lekarskie PZWL, 2007 [In Polish].

15. Linskens H.F.: Papierchromatographie in der Botanic. Springer verl. Berlin-Göttinger-Heidelberg 1959.

16. Mróz P. et al.: Chromatograficzne metody izolacji i identyfikacji fenolokwasów. Biul. Wydz. Farm. WUM, 6, 40, 2012 [In Polish].

17. Naora H. et al: On the structure of ailanthone, a bitter principle from Ailanthus altissima. Chem. Lett., 5, 661, 1982.
18. Noteboom H. P.: Flavonols, leuco-anthocyanins, cinnamics acid and alkaloids in dried leaves of some Asiatic and Malesian Simaroubaceae, Blumea, 14, 309, 2966.

19. Ohmoto T., Koike K., Sakamoto Y.: Studies on the constituens of Ailanthus altissima Swingle. II. Alkaloid constituents. Chem. Pharm. Bull., 29, 390, 1981.

20. Ohmoto T., Tanaka R., Nikaido T. Studies on constituents of Ailanthus altissima Swingle. On the alkaloidal constituents. Chem. Pharm. Bull., 24, 1532, 1976

21. Perkin A.G., Wood P.J.: Proceedings of the Chemical Society. Proc. Chem. Soc., 14, 105, 1898.

22. Randerth K.: Dünnschicht - Chromatographie verl. Chemia, Weinbeim 1962.

23. Sarwa A.: Wielki leksykon roślin leczniczych. Książka i Wiedza, Warszawa 2001 [In Polish].

24. Sarwa A.J.: Tajemnice czterystu ziół. Oficyna Wydawnicza KARAT, Tarnów 1995 [In Polish].

25. Schmidtlein H., Herrmann K.: Quantitative analysis for phenolic acids by thin layer chromatography. Chromatogr., 115, 123, 1975.

26. Smolarz H.D., Waksmundzka-Hajnos M.: Two-dimensional TLC of phenolic acids on cellulose. J. Planar Chromatogr., 6, 278, 1993.

27. Souleles C. and Philianos S.: Constituents of Ailanthus glandulosa leaves. Plant. Med. Phytother., 17, 157, 1983.

28. Szendrei K. et al.: $\beta$-Carboline alkaloids and coumarins from the Root bark of the tree-of-heaven [Ailanthus altissima (Mill.) Swingle, Simaroubaceae]. Herba Hung., 16, 15, 1977.

29. Zhang LP. et al.: Two new alkaloidal glycosides from the root bark of Ailanthus altissima. J Asian Nat Prod Res., 9, 253, 2007.

30. Zhao C., Shao J., Li X.: Chemical constituents from fruits of Ailanthus altissima. Zhongguo Zhong Yao Za Zhi., 34, 2197, 2009. 